Gayana Bot. 65(1): 84-92, 2008

ISSN 0016-5301

\title{
COMPARATIVE FOLIAR EPIDERMAL MORPHOLOGY OF THE WEST AFRICAN SPECIES OF THE GENUS AFZELIA SMITH (LEGUMINOSAE: CAESALPINIOIDEAE).
}

\section{ESTUDIO COMPARATIVO DE LAEPIDERMIS DE LA HOJA DE ESPECIES DEL GENERO AFZELIA SMITH (LEGUMINOSAE: CAESALPINIOIDEAE)DEAFRICA OCCIDENTAL}

\author{
Akeem Babalola Kadiri \& James Dele Olowokudejo \\ University of Lagos, Department of Botany and Microbiology, Akoka Lagos, Nigeria. \\ abkadiri2001@yahoo.com, deledejo2005@yahoo.co.uk
}

\begin{abstract}
The epidermal features of the leaves of the six West African species of Afzelia were examined and compared using light and scanning electron microscopy. The leaves are hypostomatic in all species and stomatal type is paracytic. Anticlinal walls may be undulate or straight-curved and stomatal index ranges from $17.48 \%$ in A. bella var. gracilior to $25.20 \%$ in $A$. bipindensis. Porrect and flattened scales distinguish the infra-specific taxa of $A$. bella while presence of unicellular trichomes separates A. pachyloba from other species. The leaf surface is entirely covered by epicuticular wax deposits and the stomata are either raised or sunken in the genus. Using these foliar epidermal characters, an artificial key has been prepared to facilitate identification of the species.
\end{abstract}

KEYwords: Afzelia, stomata, epidermal cell, morphology, taxonomy.

\section{RESUMEN}

Características de la epidermis de las hojas de seis especies de Afzelia del Africa occidental fueron examinadas y comparadas usando microscopios de luz y electrónico. Las hojas son hipostomáticas en todas las especies, y presentan estomas paracíticos. Paredes anticlinales pueden ser onduladas o recto-curvadas, y el índice estomático va de 17,48\% en $A$. bella var. gracilior a 25,20\% en A. bipindensis. Escamas aplastadas y extendidas distinguen los taxa infraespecíficos de $A$. bella, mientras que la presencia de tricomas unicelulares separa a A. pachyloba de las demás especies. La superficie de las hojas está enteramente cubierta por depósitos de cera epicuticular, y los estomas se presentan elevados o hundidos. Usando estos caracteres epidérmicos foliares, se preparó una clave artificial para facilitar la identificación de las especies.

Palabras Claves: Afzelia, estomas, células epidérmicas, morfología, taxonomía.

\section{INTRODUCTION}

The genus Afzelia Smith is represented by six species in West Africa, out of which one species has two varieties. Most of the species are well distributed in Nigeria (Hutchinson \& Dalziel 1958). The plant is economically useful. Burkill (1994) documented A. africana Sm., A. bella Harms, A. bipindensis Harms, A. bracteata T.Vogel and $A$. pachyloba Harms as the commercial species in West Africa. But A. bijuga A.Gray = Intsia bijuga (Celebr.)
Kuntze is insufficiently known (Hutchinson \& Dalziel 1958). The species are a good source of timber for construction works such as railways, buildings and canoes, for making mortars and pestles, charcoal, burnt wood is for producing soap and they are a good source of dye. Medicinally, the bark and leaves are used as febrifuge and analgesic medicine; also, they are useful in curing dermal infections and relieving kidney pains, the bark-decoction cures stomach-ache, controls hemorrhage in laboring women, cures heart and chest troubles, and it also has wound-healing 
properties. The bark is also aphrodisiac, the shoots and fruits are used to control menstrual problems and promote penile erection. Root-decoction is used to cure gonorrhea and can be used as poisoning antidote. The seeds are poisonous when matured but they are used for ornamental purposes. The foliage is good cattle fodder and the species are good for restocking savanna woodland (Burkill 1994).

The foliar epidermal features documented on the family Leguminosae by Metcalfe \& Chalk $(1950,1979)$ were used as a guide in the present study towards understanding the foliar endo-morphology of the genus. Wood morphological characteristics; albeit, not investigated in the present account, of some species of the genus have been also being reported by Germishuizen et al. (2005) and Okeke (1966). Therefore, this present investigation of the leaf epidermal characters was undertaken using both light and scanning electron microscopy to facilitate the understanding of the taxonomic relationship of the species of the genus and to aid recognition of the species even when they are available as leaf fragments and to provide useful taxonomic data on A. bijuga which hitherto is a poorly reported taxon. The taxonomic relevance of foliar epidermal characters of angiosperms has been well documented (Inamdar \& Gangadhara 1977; Kotresha \& Seetharam 1995, 2000; Ogundipe \& Wujek 2004; Ogundipe \& Akinrinlade 1998; Olowokudejo \& Pereira-Sheteolu 1988).

\section{MATERIALAND METHODS}

Herbarium specimens obtained from the Forestry Research Institute of Nigeria, Ibadan (FHI) were used for the study. Leaf epidermal preparations involved cutting one to five centimetres square portions from the standard median portion of the leaf lamina near the mid-rib and then swelled by boiling in water for thirty minutes. The leaf pieces were later soaked in concentrated trioxonitrate (v) acid $\left(\mathrm{HNO}_{3}\right)$ in capped specimen bottles for about eight to twenty-four hours to macerate the mesophyll. Tissue disintegration was indicated by bubbles, and the epidermises were transferred into Petri dishes containing water for cleansing and then, epidermises were separated with forceps and mounting needles. Tissue debris was cleared off the epidermises with a fine-hair brush and washed in several changes of water. Drops of different grades of Ethanol: 50\%, 70\%, 75\% up to $100 \%$ were added in turn to harden the cells. Preparations were later stained with Safranin O in 50\% alcohol for about five minutes before mounting in glycerine on the glass slide. The epidermises were mounted on the glass slide with upper surfaces facing up and then covered with cover-slips and ringed with nail varnish to prevent dehydration.

Slides were examined with light microscope at $\mathrm{x}$ 100 , and $x 400$. Stomata and trichome indices were calculated using the formulae of Stace (1965):

$$
\begin{aligned}
\text { Stomata index } & =\frac{\text { Stomata number X } 100}{\text { Cell number per unit area }+ \text { stomata number }} \\
\text { Trichome index } & =\frac{\text { Trichome number X } 100}{\text { Cell number per unit area }+ \text { trichome number }}
\end{aligned}
$$

For SEM small pieces $\left(7 \mathrm{~mm}^{2}\right)$ of the leaf material were fixed on SEM stubs with double-sided tape, coated with gold in a sputter coater, and examined and photographed in Jeol JSM 35 SEM. All were studied at tilt angle of $0^{0}$.

Summaries of the result are presented in Figures 1-5 and Tables I-II. The voucher specimens studied are A. africana- FHI 425 collected by Dalziel, J.M in Katagum district, Nigeria 1908; A. pachyloba- FHI 38597, collected by Onochie C.F.A. in Okomu forest Reserve, Nigeria in 1955; A. bipindensis- FHI 8889 was collected by P.W. Richards \& Co. in Okomu forest reserve; A. bracteata- FHI 890 was collected by Hutchinson and Dalziel in 1861; A. bella var. bellaFHI 14144 was collected by Chevalier, A. in Calabar province, Nigeria; A. bella var. gracilior- FHI 5815 was collected in Kumasi, Ghana, by Andoh, J. E. in 1953 and A. bijuga FHI 2695 was collected in Cameroon.

\section{RESULTSANDDISCUSSION}

The leaf is generally hypostomatic, anticlinal walls are usually straight, curved to undulate and cell shape is either irregular or isodiametric (Figs. 1-3, Table I). 


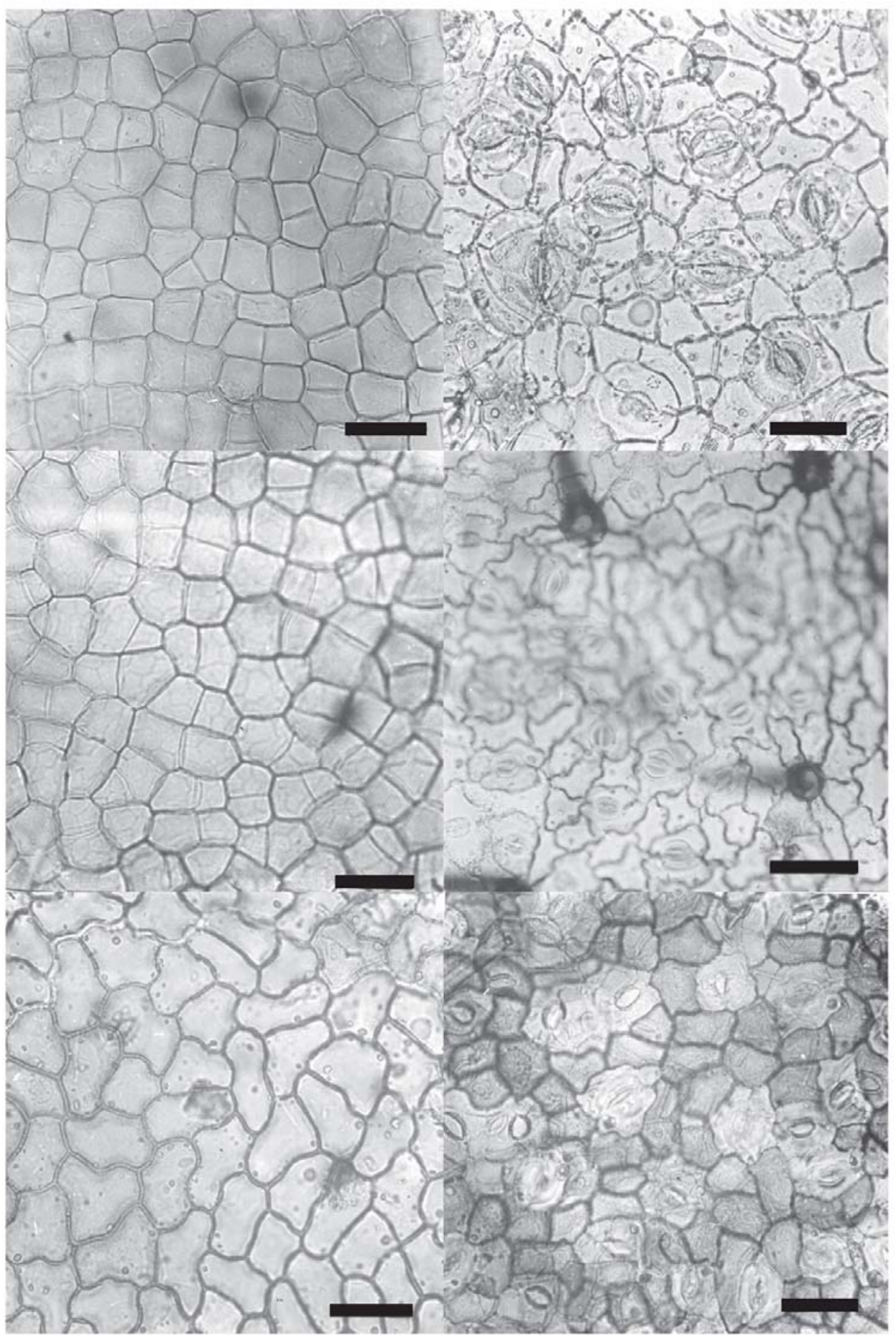

Figure 1. Epidermides of the species of Afzelia in West Africa. a, b: A. africana; c, d: A. pachyloba; e, f: A. bipindensis. a, c, e: adaxial surface, b, d, f: abaxial surface. Scala $=50 \mu \mathrm{m}$.

Figura 1. Epidermis de las especies de Afzelia en Africa occidental. a, b: A. africana; c, d: A. pachyloba; e, f: A. bipindensis. a, c, e: superficie adaxial, b, d, f: superficie abaxial. Escala $=50 \mu \mathrm{m}$. 


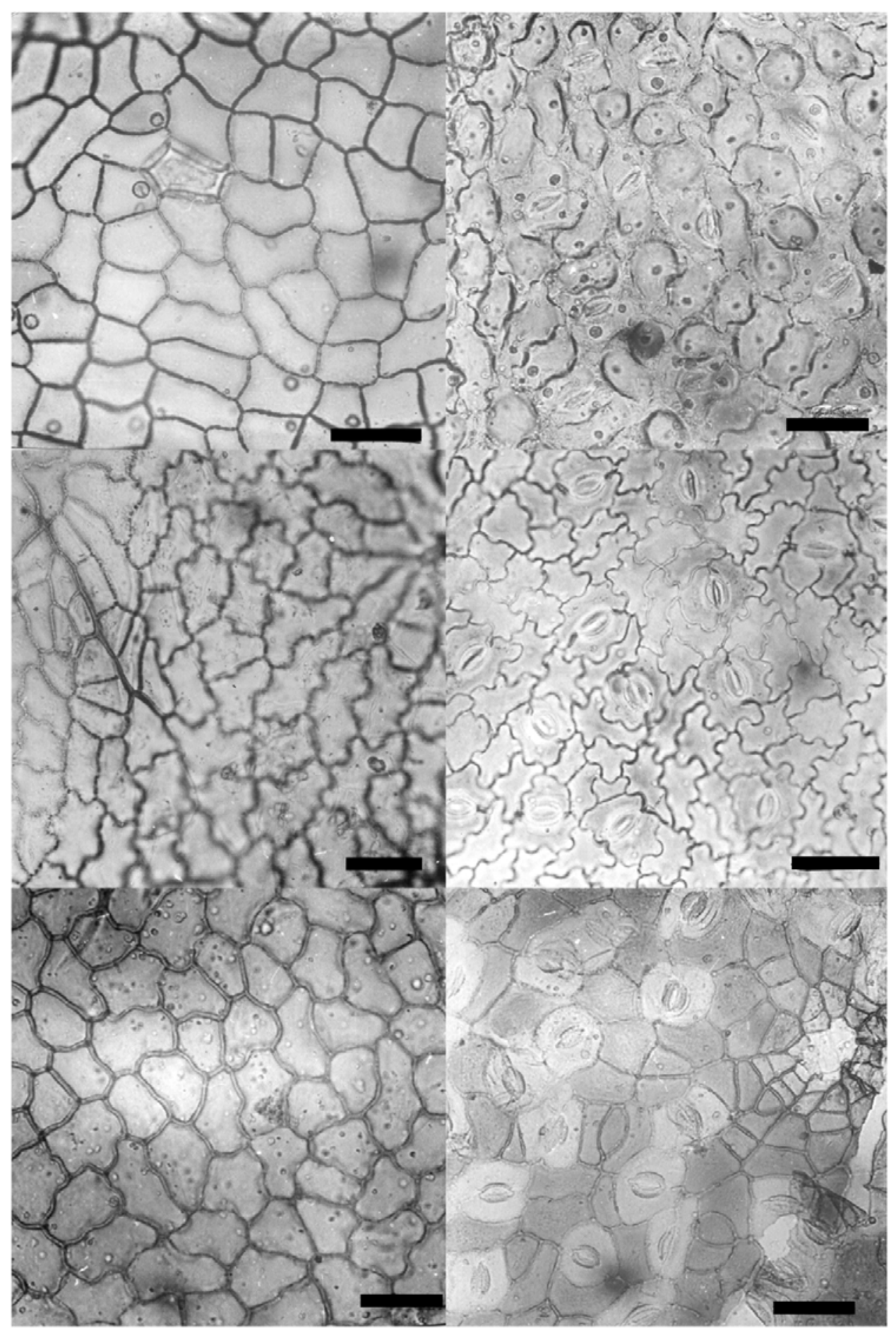

Figure 2. Epidermides of the species of Afzelia in West Africa. a, b: A. bracteata; c, d: A. bella var. bella; e, f: A. bella var. gracilior. a, c, e: adaxial surface, b, d, f: abaxial surface. Scale $=50 \mu \mathrm{m}$.

Figura 2. Epidermis de las especies de Afzelia en Africa occidental. a, b: A. bracteata; c, d: A. bella var. bella; e, f: A. bella var. gracilior. a, c, e: superficie adaxial, b, d, f: superficie abaxial. Escala $=50 \mu \mathrm{m}$. 
Gayana Bot. 65(1), 2008

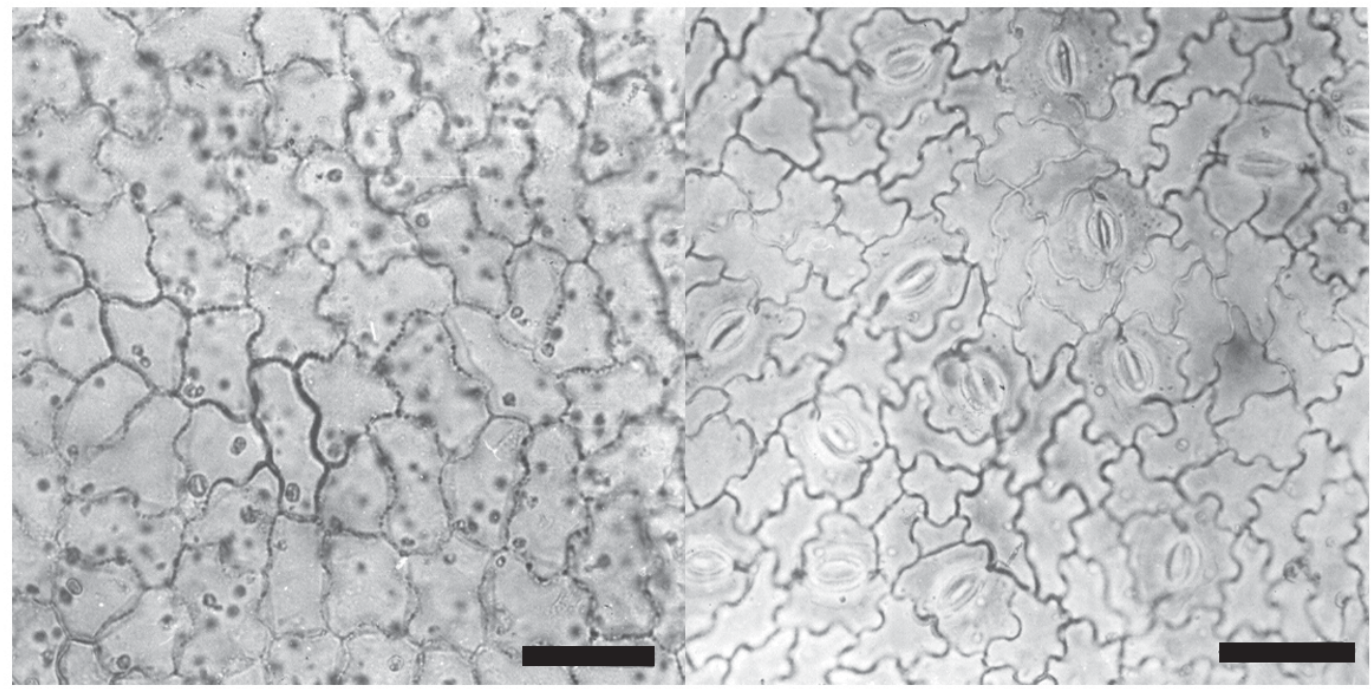

Figure 3. Epidermides of the species Afzelia bijuga in West Africa. a (adaxial); b (abaxial): Scale $=50 \mu \mathrm{m}$.

FIgURA 3. Epidermis de la especie Afzelia bijuga en Africa occidental. a (adaxial); b (abaxial): Escala $=50 \mu \mathrm{m}$.

TABLE I. Foliar epidermal features of the species of Afzelia in West Africa.

TABLA I. Características de las epidermis foliar de las especies de Afzelia de Africa Occidental.

\begin{tabular}{|c|c|c|c|c|c|c|}
\hline Species & Cell shape $^{1}$ & Wall pattern ${ }^{1}$ & $\begin{array}{c}\text { Trichome }^{1} \\
+/-\end{array}$ & $\begin{array}{c}\text { X Cell } \\
\text { number }^{1}\end{array}$ & $\begin{array}{c}\text { Stomata } \\
\text { Mean number }\end{array}$ & $\begin{array}{c}\text { Cell width Mean }{ }^{3} \pm \\
\text { S.E }(\mu \mathrm{m})\end{array}$ \\
\hline A. africana & irr/irr & und/und & $-1-$ & 137 / 103 & 23 & $29.9 \pm 1.5$ \\
\hline A. bella var. bella & irr/irr & und/und & $-1-$ & $86 / 83$ & 20 & $32.2 \pm 2.1$ \\
\hline A. bella var. gracilior & iso/iso & curv/curv & $-/-$ & $94 / 85$ & 18 & $35.6 \pm 1.4$ \\
\hline A. bijuga & irr/ irr & und / und & $-/-$ & 102 / 97 & 24 & $27.1 \pm 2.5$ \\
\hline A. bipindensis & iso / iso & curv / curv & $-/-$ & $111 / 95$ & 32 & $26.3 \pm 1.3$ \\
\hline A. bracteata & iso / irr & curv / und & $-/-$ & $86 / 68$ & 18 & $32.7 \pm 1.6$ \\
\hline A. pachyloba & $\operatorname{irr} / \operatorname{irr}$ & und / curv & $+/+$ & 100 / 84 & 21 & $25.1 \pm 1.2$ \\
\hline
\end{tabular}

irr = irregular, iso = isodiametric, und = undulate, curv = curved. ${ }^{1}$ adaxial/abaxial surfaces; ${ }^{2}$ abaxial surface; ${ }^{3}$ adaxial surface. irr = irregular; iso = isodiamétrica, und = undulada, curv = curvada. ${ }^{1}$ cara adaxial $/$ abaxial; ${ }^{2}$ cara abaxial; ${ }^{3}$ cara adaxial . 
Paracytic stomata are common in the genus (Figs. 1-3), but other accompanying stomata types include cyclocytic, which were recorded in A. africana, $A$. pachyloba, A. bracteata, A. bella var. bella, A. bijuga and diacytic in A. pachyloba (Figs. 1b, 2b, d, $3 b)$. In the general anatomical account of the familyLeguminosae by Metcalfe \& Chalk (1950, 1979); hypo- and amphistomata, regular, irregular, polygonal to isodiametric cells, paracytic, anomocytic stomata and others were reported by them. Mean epidermal cell varies from 86 in $A$. bracteata and A. bella var. bella to 137 in A. africana on the adaxial surface, whereas the value ranges from 68 in A. bracteata to 103 in A. africana on the abaxial surface. Epidermal cell width is slightly larger on the adaxial surface than the abaxial surface, in all, the value ranges from $13.3(23.1 \pm 2.1)$ $36.6 \mu \mathrm{m}$ in A. bijuga on the abaxial surface to 25.0 (35.6 \pm 1.4$) 50.0 \mu \mathrm{m}$ in A. bella var. gracilior on the adaxial surface. Stomatal size varies from 10.0 (13.0 \pm 0.5$) 15.0 \mu \mathrm{m} \times 6.7(6.8 \pm 0.1) 7.2 \mu \mathrm{m}$ in A. bijuga to $16.7(21.2 \pm 1.0) 33.3 \mu \mathrm{m} \times 6.7(6.8 \pm 0.1) 7.0 \mu \mathrm{m}$ in A. bella var. gracilior. Stomatal index has proved useful in aiding the recognition of the species, its value ranges from $17.48 \%$ in $A$. bella var. gracilior to A. bipindensis in $25.20 \%$ (Table II).

TABLE II. Quantitative characters of the stomata of the species of Afzelia in West Africa.

TABla II. Caracteres cuantitativos de los estomas de las especies de Afzelia en Africa Occidental.

\begin{tabular}{lccc}
\hline Species & $\begin{array}{c}\text { Stomata Length }(\mu \mathrm{m}) \\
\text { Min. (Mean } \pm \text { S.E) Max }\end{array}$ & $\begin{array}{c}\text { Stomata Width }(\mu \mathrm{m}) \\
\text { Min. (Mean } \pm \text { S.E) Max. }\end{array}$ & Stomata Index $(\%)$ \\
\hline A. africana & $16.7(20.6 \pm 0.4) 26.6$ & $3.3(4.7 \pm 0.3) 6.7$ & 18.3 \\
A. bella var. bella & $16.7(19.7 \pm 0.4) 23.3$ & $6.7(6.9 \pm 0.1) 7.4$ & 19.4 \\
A. bella var. gracilior & $16.7(21.2 \pm 1.0) 33.3$ & $6.7(6.8 \pm 0.1) 7.0$ & 17.5 \\
A. bijuga & $10.0(13.0 \pm 0.5) 15.0$ & $6.7(6.8 \pm 0.1) 7.2$ & 22.4 \\
A. bipindensis & $13.3(15.3 \pm 0.3) 16.7$ & $6.7(7.9 \pm 0.3) 10.0$ & 25.2 \\
A. bracteata & $15.0(16.8 \pm 0.3) 20.0$ & $6.7(6.9 \pm 0.1) 7.1$ & 20.9 \\
A. pachyloba & $10.0(16.0 \pm 0.7) 23.3$ & $6.7(6.9 \pm 0.1) 7.1$ & 20.0 \\
\end{tabular}

All the species are glabrous except $A$. pachyloba with simple unicellular conical trichomes which usually have basal cells (Fig. 1d). This feature distinguishes A. pachyloba from other members of the genus and corroborates the earlier report that simple unbranched hairs may be common or not seen (Metcalfe 1950, 1979). Another distinctive feature of the genus is presence of sessile scales which distinguishes A. pachyloba and A. bella from other species in the group; also, the porrect and flattened scale types in $A$. bella supports the recognition of the infra-specific individuals in the species. Crystals of calcium oxalate were recorded on the adaxial surface of the epidermal cells of $A$. bipindensis and
A. bracteata but in A. bijuga, the crystals are present on both surfaces of the epidermal cell. But crystal has not been reported before in the genus (Germishuizen et al. 2005; Metcalfe \& Chalk 1950, 1979; Okeke 1966). The epidermal features were covered with heavy deposits of epicuticular wax in all the species (Figs. 4-5). Wax is either rough in A. pachloba and $A$. africana but it is smooth in other species (Figs. 4-5). Leaf veins are usually cutinized in A. pachyloba and A. bipindensis (Fig. 4 c-f). Stomata are either raised in A. bracteata and A. bella var. bella or sunken in other species studied (Figs. 4 b, 5 a-c, e).Usually, the stomata aperture are either narrow or wide in the species (Figs. $4 \mathrm{~b}, 5 \mathrm{a}-\mathrm{c}$, e). 


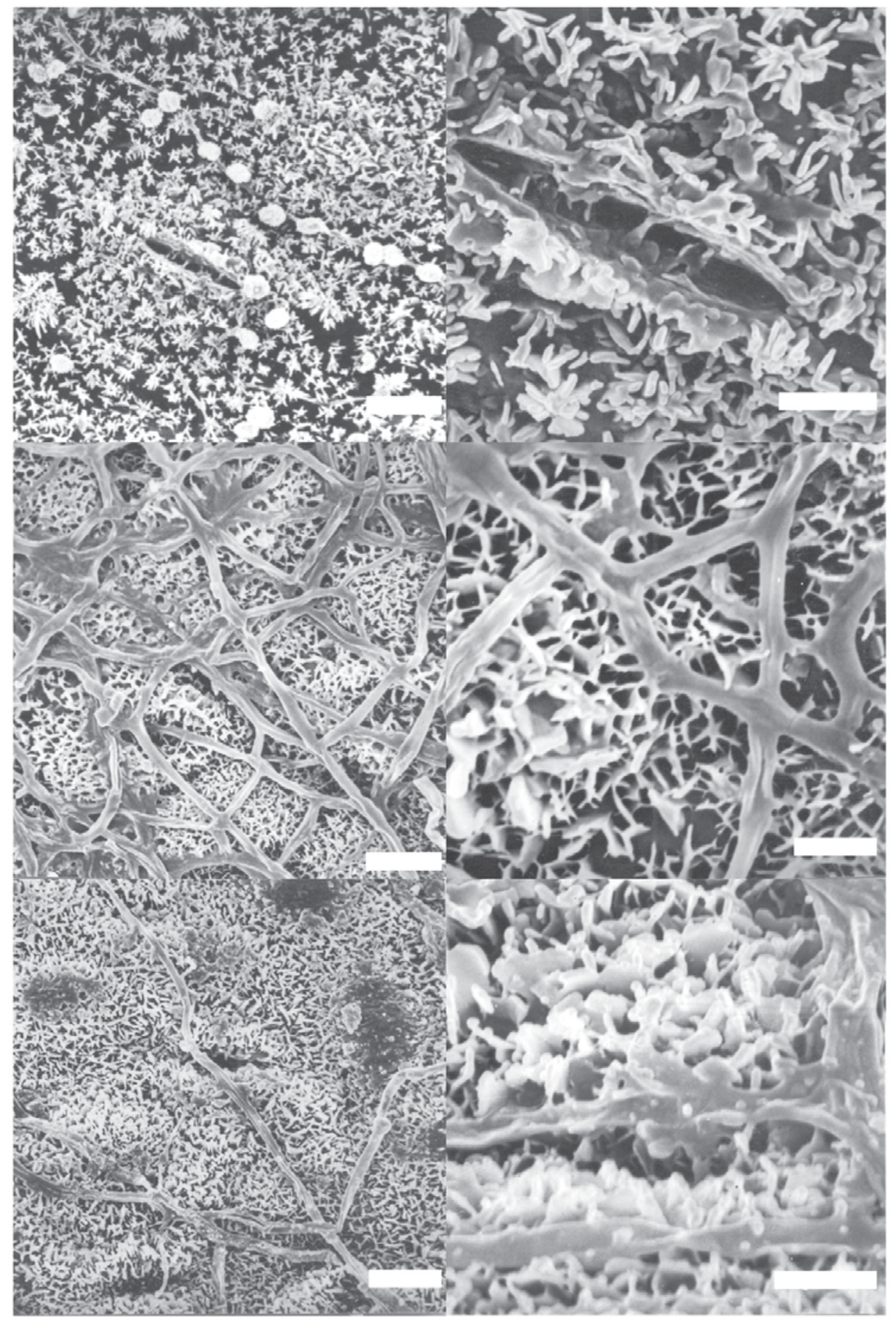

FiguRE 4. Scanning Electron micrographs of the leaf surfaces of the species of Afzelia. a, b: A. africana; c, d: A. pachyloba; e, f: A. bipindensis. a, b: adaxial surface, c - f: abaxial surface. Scale $=50 \mu \mathrm{m}$.

Figura 4. Fotomicrografías de la superficie de la hoja de las especies de Afzelia. a, b: A. africana; c, d: A. pachyloba; e, f: A. bipindensis. a, b: superficie adaxial, c - f: superficie abaxial. Escala $=50 \mu \mathrm{m}$. 


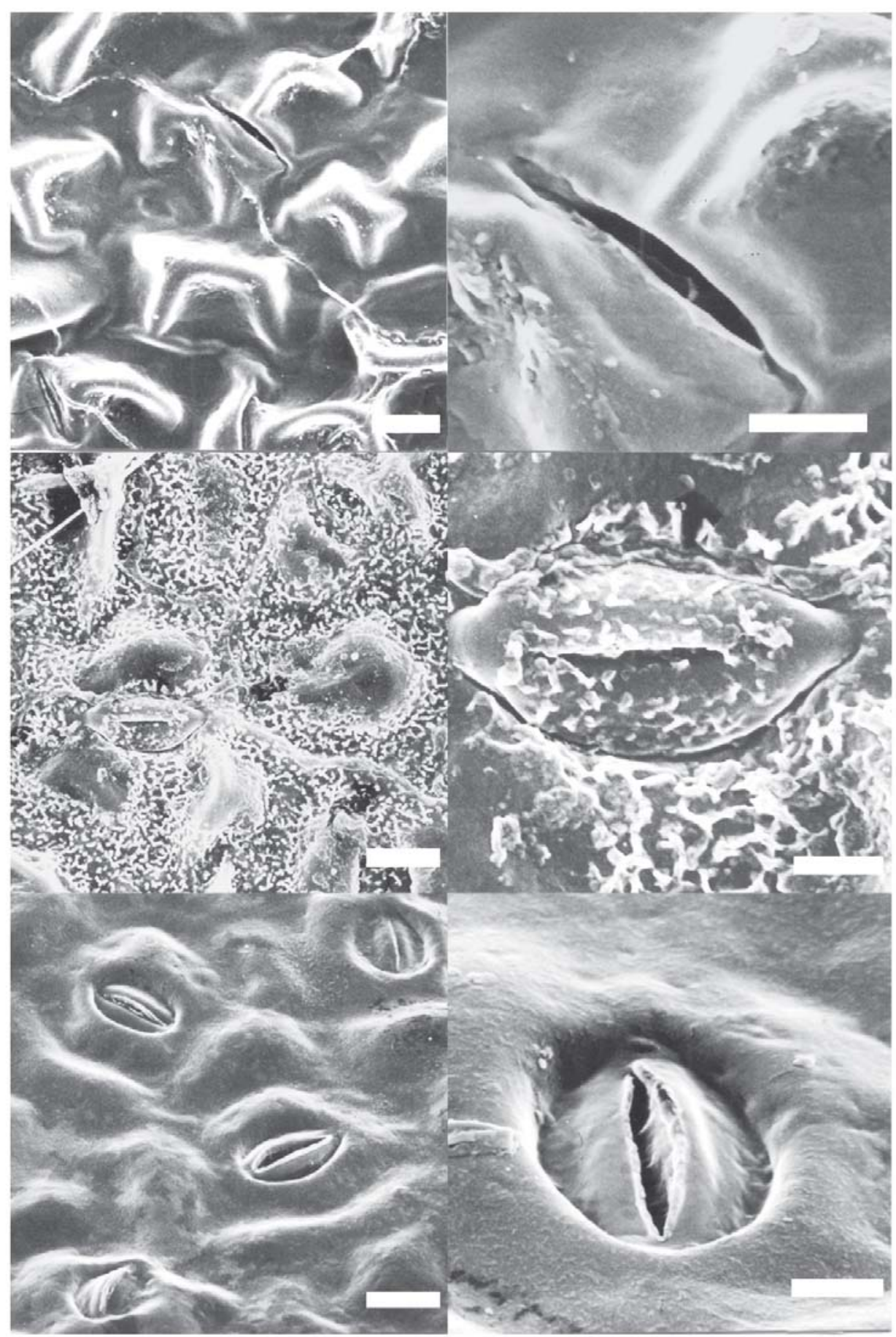

FIGURE 5. Scanning Electron micrographs of the leaf surfaces of the species of Afzelia. a, b: A. bracteata; c, d: A. bella var. bella; e, f: A. bella var. gracilior. All abaxial surface. Scale $=50 \mu \mathrm{m}$.

Figura 5. Fotomicrografías de la superficie de la hoja de Afzelia. a, b: A. bracteata; c, d: A. bella var. bella; e, f: A. bella var. gracilior. Todas superficies abaxiales. Escala $=50 \mu \mathrm{m}$. 
Gayana Bot. 65(1), 2008

With these features, the genus can be distinguished from other genera of the family by comparison of the values obtained on all the features studied. In the same vein, the species too, can be delimited with ease. Therefore, an artificial key is presented below to separate the species.

Artificial key to the species of AfZelia in West Africa

1. Leaf pubescent, anticlinal wall undulate-curved on both surfaces. Stomatal index 20\%............A. pachyloba 1. Leaf glabrous, anticlinal wall undulate, straight- curved on either surface

2. Stomatal sunken, wax rough. A. africana

2. Stomatal either sunken or raised, wax smooth.

3. Maximum stomata length not up to $25 \mu \mathrm{m}$, scale flattened........................................... bella var. bella

3. Maximum stomata length above $25 \mu \mathrm{m}$, scale porrect A. bella var. gracilior

4. Crystals of calcium oxalate present on both surfaces, epidermal cell width equal on both surfaces.

4. Crystals of calcium oxalate present on the adaxial surface only, epidermal cell width unequal on either surface.

5. Stomata sunken

A. bipindensis

5. Stomata raised

A. bracteata

\section{CONCLUSION}

The inter-specific taxonomic relationships existing in Afzelia can be investigated by the use of some endo-qualitative and quantitative characteristics of the leaf such as epidermal surfaces, epicuticular wax, stomatal size, crystals and stomatal orientation. A bijuga which is the least reported taxon is now documented to possess glabrous leaf surfaces, crystals, irregular cell shape and undulate anticlinal walls on both surfaces of the leaf epidermis. The present study has also confirmed earlier reports of workers and new taxonomic data have been recorded for the genus. Many of these features are both specific and generic constant, and they can be used to facilitate the recognition of the species and help in solving problems of adulteration in the commercial species even when the leaf is fragmentary.

\section{BIBLIOGRAPHY}

BurkiLl, H. M. 1994. The Useful Plants of West Tropical Africa ( $2^{\text {nd }}$ Edition) Vol. 2. Royal Botanic Garden, Kew. pp. 21-25.

Germishuizen, G., N.R. Crouch \& G. Condy. 2005. Afzelia quanzensis. Flowering Plant of Africa 59: 74-83.

Hutchinson, J. \& J.M. Dalziel. 1958. Crown Agents for overseas Governments and Administrations. Flora of West Tropical Africa 1(2). London. 828 pp.
InAmDar, J. A. \& M. Gangadhara. 1977. Studies on the trichomes of some Euphorbiaceae. Feddes Repertorium. 88: 103-111.

Kotresha, K. \& Y.N. Seetharam. 1995. Epidermal studies in some species of Bauhinia L. (Caesalpinioideae). Phytomorphology 45(1-2): 127-137.

Kotresha, K. \& Y.N. Seetharam. 2000. Epidermal micromorphology of some species of Cassia L. (Caesalpiniaceae). Phytomorphology 50(3-4): 229-237.

Metcalfe, C.R. \& L. Chalk. 1950. Anatomy of the Dicotyledons. Oxford University Press, Oxford. 724 pp.

Metcalfe, C.R. \& L. Chalk. 1979. Anatomy of the Dicotyledons ( $2^{\text {nd }}$ ed.). Vol. 1 . Oxford University Press, Oxford. 276 pp.

Ogundipe, O.T. \& O.O. AKInRINLAde. 1998. Epidermal Micromorphology of Some Species of Albizia Durazz (Mimosaceae). Phytomorphology 48 (23): 217-323.

Ogundipe, O.T. \& D.E. WuJEK. 2004. Foliar anatomy on twelve genera of Bignoniaceae (Lamiales). Acta Botanica Hungary 46: 290 - 312.

OKeкE, R.E. 1966. Comparative Anatomy of three Nigerian Afzelia species. Forest Products Research Report 9: 8

Olowokudejo, J.D. \& O. Pereira-Sheteolu. 1988. The taxonomic value of epidermal characters in the genus Ocimum (Lamiaceae) Phytomorphology 38 (2-3):147-158

Stace, C.A. 1965. Cuticular studies as an aid to plant taxonomy. Bulletin of British Museum (Natural History) Botany 4: 3-78. 